\title{
Persahabatan: Sumbangsih Moralitas Tradisi Kristen bagi Moralitas Bangsa Indonesia
}

\author{
Hendrawan Wijoyo* \\ *Penulis memperoleh gelar S.Th. dari Seminari Alkitab Asia Tenggara pada 2016 dan kini sedang melayani \\ sebagai hamba Tuhan di Gereja Pemberita Injil dan berencana memperdalam studinya dalam bidang teologi \\ biblika dan etika Kristen. \\ Email: hw.abisha@gmail.com
}

\begin{abstract}
Abstrak: Untuk betul-betul menjadi terang, kekristenan perlu menggumulkan sumbangsihnya bagi moralitas bangsa. Menggunakan ide tradisi Alasdair MacIntyre dan teologi natural Alister McGrath, penulis menawarkan sebuah konstruksi teologi yang membuka kemungkinan ide moralitas Kristen diperhitungkan dalam pembicaraan moralitas bangsa. Penulis kemudian menawarkan konsep persahabatan dalam kekristenan sebagai contoh nyata sumbangsih kekristenan bagi moralitas bangsa.
\end{abstract}

Kata-kata Kunci: Alasdair MacIntyre, Alister McGrath, Aristoteles, Etika, Persahabatan, Teologi Publik, Thomas Aquinas

Abstract: Christians in Indonesia are often depicted as free riders who don't contribute much to Indonesian's independence and life as nation. This is a false claim. However, Christianity does need to offer a greater contribution, especially in the area of moral thought of Indonesia which is dominated by Islamic theology and secular ideas. Using the framework of Alasdair MacIntyre and Alister McGrath, this article constructs a theological and philosophical basis for Christianity's contribution for the nation's morality discussions. In the later part of this article, a Christian conception of friendship will be offered as an example of a Christian contribution.

Keywords: Alasdair MacIntyre, Alister McGrath, Aristotle, Ethic, Friendship, Public Theology, Thomas Aquinas 


\section{Pendahuluan}

James Gustafson empat dekade lalu mengeluhkan kurangnya peran Alkitab dalam diskusi etika dan moralitas Kristen. ${ }^{1}$ Melihat publikasi selama beberapa puluh tahun terakhir, rasanya keluhan Gustafson telah terjawab. Isu demi isu dalam diskusi moralitas dan etika telah coba diterangi dari sudut pandang Alkitab. ${ }^{2}$ Persoalan hermeneutis yang terlibat dalam pemakaian Alkitab sebagai dasar moralitas Kristen juga telah diulas. ${ }^{3}$ Bagian-bagian Alkitab yang sarat implikasi etis dan moral pun telah diperhatikan. ${ }^{4}$ Kehidupan Kristen yang menjalankan moralitas Kristen pun sudah pula mendapat perhatian. ${ }^{5}$

Dari banyak isu relevansi Alkitab dengan diskusi moral, ada salah satu isu yang menanti

${ }^{1}$ James Gustafson, "The Place of Scripture in Christian Ethics: A Methodological Study,” Interpretation 24 (1970), 430-455, terutama 431, bdk. Charles Cosgrove, Appealing to Scripture in Moral Debate: Five Hermeneutical Rules (Grand Rapids: Eerdmans, 2002), 1. Pada tahun yang sama, Brevard Childs mengutarakan pengamatan yang sama: "there is no outstanding modern work written in English that even attempts to deal adequately with the Biblical material as it relates to ethics" (Biblical Theology in Crisis [Philadelphia: Westminster, 1970], 124).

${ }^{2}$ Allen Verhey, Reading Bible in the Strange World of Medicine (Grand Rapids: Eerdmans, 2003); Lisa Cahill dan James Childress, ed., Christian Ethics: Problem and Prospect (Cleveland: Pilgrim, 1996); John Feinberg dan Paul Feinberg, Ethics for a Brave New World (ed. ke-2; Wheaton: Crossway, 2010).

${ }^{3}$ Cosgrove, Appealing to Scripture; Walter Kaiser, Toward Old Testament Ethics (Grand Rapids: Academie, 1983); Stanley Hauerwas, A Community of Character (Notre Dame: University of Notre Dame Press, 1981); dll.

${ }^{4}$ Carl Braaten dan Christopher Seitz, ed., I Am the Lord Your God: Christian Reflection on Ten Commandments (Grand Rapids, 2005); Eka Darmaputera, Sepuluh Perintah Allah: Museumkan Saja? (Yogyakarta: Gloria Graffa, 2005); James Thompson, Moral Formation according to Paul: The Context and Coherence of Pauline Ethics (Grand Rapids: Baker, 2011).

${ }^{5}$ David Gill, Doing Right: Practicing Ethical Principle (Downers Grove: Inter-Varsity, 2004); C.J. Mahaney, ed., Worldliness (Wheaton: Crossway, 2013); sebagian dari Bruce Birch dan Larry Rasmussen, Bible and Ethics in Christian Life (Minneapolis: Augsburg, 1989). untuk dibahas lebih dalam. ${ }^{6}$ Isu tersebut adalah adalah aplikasi konsep moral kristiani di ranah publik. ${ }^{7}$

Mengaplikasikan moralitas Kristen dalam konteks gereja cenderung mudah sebab Alkitab, teologi Kristen, dan moralitasnya mendapat tempat sebagai fondasi yang otoritatif bagi kehidupan gereja. Posisi istimewa ini tidaklah didapat moralitas Kristen, ketika konsep moral Kristen dibawa ke ranah publik Indonesia. Di ranah publik Indonesia, moralitas Kristen hanyalah salah satu pemain dari banyaknya pemain yang sama-sama berdagang di pasar ideologi Indonesia. Atas dasar apa gereja berharap konsep moralitas Kristen diindahkan dalam diskusi moralitas bangsa? Apa kontribusi nyata yang bisa kekristenan berikan dalam diskusi moralitas bangsa ini?

Melalui artikel ini, penulis akan menjawab kedua pertanyaan di atas dengan menawarkan dasar moralitas Kristen dalam diskusi moralitas bangsa dan satu contoh konsep moralitas Kristen yang bisa dibawa dalam diskusi tersebut. Pada bagian yang pertama, penulis akan menggunakan analisis moralitas Alasdair MacIntyre dan teologi natural Alister McGrath sebagai dasar moralitas bangsa untuk bersuara di diskusi moralitas bangsa. Pada bagian yang kedua, penulis akan mengajukan persahabatan sebagai suatu contoh nyata dari kontribusi yang bisa diberikan tradisi Kristen.

\footnotetext{
${ }^{6}$ Moral dan etika terkait erat sekalipun tidak sepenuhnya sama. Secara etimologis, arti kedua kata ini sama sekalipun berasal dari bahasa yang berbeda (K. Bertens, Etika [cet. ke-2; Jakarta: Gramedia, 1994]). Moral dan moralitas berbicara tentang kehidupan yang baik, yang seharusnya, dan yang layak dihidupi. Etika adalah penelaahan rasional terhadap perilaku benar salah yang berkaitan dengan moralitas (Wayne Boulton, Thomas Kennedy, dan Allen Verhey, "An Introduction to Christian Ethics" dalam From Christ to the World [Grand Rapids: Eerdmans, 1994], 1-3; bdk. Brad Kallenberg, "Positioning MacIntyre within Christian Ethics" dalam Virtues and Practices in the Christian Tradition: Christian Ethics after MacIntyre [cet. ke-2; ed., Nancey Murphy, Brad Kallenberg, dan Mark Nation; Notre Dame: University of Notre Dame Press, 2003] 45).
}

${ }^{7}$ Lih. Paul Hanson, Political Engagement as Biblical Mandate (Eugene: Cascade, 2010). 


\section{Kemandirian Rasionalitas Tradisi-tradisi dan Permasalahannya}

Kemajemukan falsafah hidup dan pandangan mengenai moralitas adalah realitas tak terelakkan dalam kehidupan bangsa Indonesia. Setidaknya ada enam agama yang diakui di Indonesia. ${ }^{8}$ Aneka ragam kepercayaan lokalreligius seperti Kejawen, Aluk Todolo, Kaharingan juga merupakan bagian dari kehidupan masyarakat Indonesia. ${ }^{9}$ Tak hanya itu, berbagai pemikiran/ideologi pun memengaruhi pemikiran masyarakat kita. ${ }^{10}$ Moralitas yang lahir dari rupa-rupa falsafah hidup ini punya irisan, namun juga perbedaan. Apa yang dianggap sebagai baik, pantas, dan terpuji di satu kepercayaan tak jarang berbeda di kepercayaan lain. ${ }^{11}$ Sesuatu yang sangat berarti bagi kehidupan dalam satu agama bisa jadi tidak bermakna apa-apa bagi ideologi lain. ${ }^{12}$

Adanya beragam falsafah yang berbeda memunculkan persoalan dalam penentuan kebijakan publik yang selalu kait-mengait dengan moralitas. Untuk menentukan tujuan dan trayek pendidikan nasional, misalnya, falsafah mana yang akan dipakai sebagai acuan? Apakah kebijakan itu seharusnya mengikuti falsafah hidup mayoritas masyarakat Indo-

${ }^{8}$ Keenam agama yang diakui tersebut menurut Penjelasan Atas Penetapan Presiden No 1 tahun 1965 tentang Pencegahan Penyalahgunaan dan/atau Penodaan Agama adalah Buddha, Hindu, Islam, Kristen Katolik, Kristen Protestan, dan Khong $\mathrm{Hu} \mathrm{Cu}$.

${ }^{9}$ Satu analisis yang baik dari falsafah tradisional-lokal dapat ditengok dalam Franz Magnis Suseno, Etika Jawa: Sebuah Analisa Falsafi tentang Kebijaksanaan Hidup Jawa (cet. ke-2; Jakarta: Gramedia, 1985).

${ }^{10}$ Untuk pengantar menuju ragam etika kuno dan modern yang berasal dari luar tradisi kepercayaan dan agama, lih. Robert Arrington, Western Ethics: An Historical Introduction (Oxford: Blackwell, 1998); Steve Wilkens, Beyond Bumper Sticker Ethics: An Introduction to Theories of Right and Wrong (ed. ke-2; Downers Grove: Inter-Varsity, 2011).

${ }^{11}$ Untuk survei agama-agama dan kepercayaan di dunia, lih. Christoper Partridge, Introduction to World Religions (ed., ke-2; Minneapolis: Fortress, 2013).

${ }^{12}$ Lih. contoh perbedaan penilaian karena perbedaan pandangan dunia antara falsafah hidup dalam Paul Hiebert, Cultural Anthropology (ed. ke-2; Grand Rapids: Baker, 1983), 35-7. nesia? Kalau demikian tentu bangsa Indonesia akan jatuh pada mayoritanisme yang merepresi kaum minoritas dan falsafahnya. ${ }^{13}$ Apakah kebijakan publik semacam ini sebaiknya ditentukan oleh satu falsafah bersama seperti Pancasila? Sekalipun dasar negara yang seharusnya diakui dan dihidupi bersama, Pancasila bukan agama atau pandangan dunia menyeluruh yang bisa menjawab semua pertanyaan moralitas bangsa. ${ }^{14}$ Komunitas dan pribadi yang memeluk falsafah-falsafah hidup ini pun tidak akan begitu saja melepaskan falsafah keagamaannya. ${ }^{15}$ Apabila mengorbankan falsafah hidup demi menekankan kesatuan pemikiran bangsa bukan jawaban, maka kita perlu memetakan diskusi moralitas bangsa ini demi solusi yang lebih baik.

Analisis Alasdair MacIntyre dapat menolong untuk memetakan persoalan di atas. ${ }^{16}$ MacIntyre mengamati bahwa kisruhnya diskusi moralitas Barat didasari oleh konsep

\footnotetext{
${ }^{13}$ Todd Donovan et al., State and Local Politics: Institution and Reform (ed., ke-4; Belmont: Wadsworth, 2015), 131.

${ }^{14}$ Studi irisan dan perbedaan satu falsafah dengan falsafah lain penting untuk dilakukan dan berkaitan dengan argumen yang dipaparkan di sini, namun waktu, ruang, dan kesempatan tidak mengizinkan. Pengantar yang baik menuju studi Pancasila bisa ditemukan di Yudi Latif, Negara Paripurna: Historisitas, Rasionalitas, dan Aktualitas (Jakarta: Gramedia, 2011).
}

${ }^{15}$ Menjadikan Pancasila sebagai satu-satunya falsafah hidup bangsa dan menundukkan semua falsafah yang berbeda dengan Pancasila tidak sesuai dengan visi yang diimpikan oleh pendiri bangsa ini. Sila pertama dari Pancasila merupakan pengingat bahwa ketuhanan dan keagamaan adalah yang pertama dan yang paling utama bagi para pendiri bangsa Indonesia. Sejarah pun membuktikan tidak semua komunitas dan pribadi dalam bangsa Indonesia akan rela melepaskan kesetiaan (allegiance) mereka kepada Tuhan mereka atau falsafah hidup mereka. Pancasila adalah kerangka yang menentukan ruang bergerak dan berpikir bagi rakyat Indonesia mengenai bangsanya, bukan obat sakti bagi semua pertanyaan dan permasalahan bangsa. Kemajemukan Indonesia menuntut solusi yang lebih kompleks dan sejalan dengan Pancasila.

${ }^{16}$ Alasdair MacIntyre, Whose Justice? Which Rationality? (Notre Dame: University of Notre Dame Press, 1988); idem, After Virtue: A Study in Moral Theory (ed. ke-3; Notre Dame: University of Notre Dame Press, 2007). Pembahasan yang menarik dan berpengaruh dalam tulisan ini atas analisis MacIntyre dapat dilihat dalam Alister McGrath, Reality (A Scientific Theology 2; Grand Rapids: Eerdmans, 2002) 64-71. 
justice (keadilan/kebenaran) yang berbedabeda. ${ }^{17}$ Di bawah berbagai konsep keadilan yang berbeda ini, terdapat rupa-rupa konsep rasionalitas yang berbeda. ${ }^{18}$ Nahasnya, perbedaan yang lebih mendasar ini jarang diangkat ke permukaan sehingga debat seputar moralitas di tingkat bangsa acap kali berubah menjadi debat kusir. ${ }^{19}$

Menghadapi realitas seperti ini, menurut MacIntyre, ada beberapa kemungkinan solusi yang tersedia. Kemungkinan yang pertama adalah mengusahakan satu sudut pandang yang netral, nirkepentingan, dan lepas dari keberpihakan pada salah satu tradisi. ${ }^{20}$ Contohnya adalah tradisi rasionalitas yang lahir dari kerangka pemikiran Pencerahan. Berbekal hukum logika dan pengamatan yang obyektif, pencarian ala Pencerahan berusaha menemukan moralitas universal yang bisa diterima semua orang yang berpikir secara rasional. ${ }^{21}$ Ironisnya, sejarah filsafat Modern menunjukkan hasil usaha ini bukanlah penemuan satu rasionalitas yang mutlak dan universal, namun setidaknya lima rasionalitas yang saling bersaing. ${ }^{22}$ Filsafat modern ternyata sekadar mampu menerangi dan menambah persoalan yang ada, tanpa mampu menyelesaikannya. ${ }^{23}$ Lama-kelamaan menjadi jelas bahwa rasionalitas-rasionalitas Pencerahan pun merupakan tradisi manusia yang

\footnotetext{
${ }^{17}$ MacIntyre, Whose, 1-2, McGrath, Reality, 66.
}

${ }^{18}$ MacIntyre, Whose, 2-3.

${ }^{19}$ Ibid. Sebagai contoh, ingat saja keributan di media mengenai Rancangan Undang-Undang pornografi dan pornoaksi di tahun 2006 yang kemudian lolos juga menjadi Undang-Undang nomor 44 tahun 2008 tentang pornografi (http://kemenag.go.id/file/dokumen/442008.pdf diakses 5 Maret 2015).

${ }^{20}$ MacIntyre, Whose, 3.

${ }^{21}$ Ibid., 6.

${ }^{22}$ MacIntyre menyebutkan kelimanya sebagai: "answers was given by the authors of the Encyclopedie, a second by Rousseau, a third by Bentham, a fourth by Kant, a fifth by the Scottish philosophers of common sense and their French and American disciples" (ibid., 6).

${ }^{23}$ Ibid., 4. terkondisi oleh ruang, waktu, dan budaya. ${ }^{24}$ Setiap tradisi rasionalitas, bahkan yang lahir dari Pencerahan, tidak dapat lepas dari keterkondisian historis dan komunitas di mana tradisi ini lahir. ${ }^{25}$

Kemungkinan yang kedua adalah mengikuti salah satu tradisi falsafah hidup yang ada. ${ }^{26}$ Daripada repot dengan argumentasi, pilihan dijatuhkan pada satu tradisi kepercayaan, agama, atau pemikiran tertentu. Menurut MacIntyre, cara penyelesaian semacam ini akan ditolak dan disebut sebagai fideisme. ${ }^{27}$ MacIntyre pun setuju dan mengingatkan bahwa rasionalitas-rasionalitas Pencerahan pun merupakan tradisi-tradisi yang menuntut komitmen iman yang kadang arbiter sehingga tidak banyak berbeda dari tradisi religius dan tradisional-lokal yang fideis. ${ }^{28}$

\footnotetext{
${ }^{24}$ McGrath, Reality, 58-9; MacIntyre, Whose, 4. MacIntryre menggunakan kata tradisi dalam pengertian: "argumen" yang berkesinambungan dalam sejarah dan dihidupi oleh komunitas tertentu. Kekristenan misalkan adalah sebuah tradisi dengan sebuah teks otoritatif dan banyak subtradisi: Lutheran, Anglikan, Kalvinis, dll. Dalam rentang narasi keberadaannya, tradisi mengalami perkembangan dan pergantian anggota, namun tetap tunduk pada satu suara atau teks tertentu (Brad Kallenberg, "The Master Argument of MacIntyre's After Virtue" dalam Virtues and Practices, 25). Dalam kata-kata MacIntyre, tradisi adalah "an argument extended through time in which certain fundamental agreements are defined and redefined in terms of two kinds of conflict: those with critics and enemies external to the tradition . . . and those internal, interpretative debates through which the meaning and rationale of the fundamental agreements come to be expressed and by whose progress a tradition is constituted" (Whose, 12).

${ }^{25}$ Ibid., 349-50.

${ }^{26}$ Ibid., 5. Bagi MacIntyre, Islam, Kristen, Yudaisme, falsafah hidup Tiongkok, atau India merupakan tradisi sebagaimana pemikiran Aristoteles dan Kant adalah sebuah tradisi pemikiran (MacIntyre, Whose, 11). Dalam pemakaian ini, penulis akan menggunakan istilah tradisi untuk menyebut keenam agama, falsafah tradisional-lokal, dan rupa-rupa ideologi lain yang ada di Nusantara.

${ }^{27}$ Ibid., 5.

${ }^{28}$ Bahkan bagi mereka bagian dari jemaat/komunitas iman semacam ini, kritikus mereka "appears to be just as much a community of prerational faith as they themselves are but one whose members, unlike themselves, fail to recognize themselves for what they are, and hence are in no position to level chargers of irrationality at them or anyone else" (MacIntyre, Whose, 5; bdk. Thomas Kuhn, The Structure of Scientific Revolutions [Chicago: University of Chicago Press, 1970]).
} 
Tak satu dari kedua kemungkinan di atas membawa kita kepada suatu rasionalitas yang berdiri di luar tradisi tertentu. Nyatanya, rasionalitas semacam itu adalah mustahil. ${ }^{29}$ Tidak ada tempat berdiri yang netral di mana seseorang bisa mengevaluasi, menerima, atau menolak suatu argumen rasionalitas selain dalam suatu tradisi tertentu. ${ }^{30}$ Lebih lanjut lagi, karena setiap tradisi memiliki pertanyaan-pertanyaan sendiri dan kriteria tersendiri untuk jawaban dan rasional yang memuaskan, tak ada satu tradisi yang dapat mengklaim lebih rasional daripada yang lain. ${ }^{31}$ Karena yang ada hanyalah berbagai tradisi yang berbeda dan hanya ada rasionalitas yang sifatnya intratradisi, maka satu tradisi tidak bisa dihakimi tradisi yang lain dari titik netral atau kriteria yang bukan berasal dari rasionalitas internalnya. ${ }^{32}$

Hal ini tidak berarti tradisi-tradisi yang bersaing ini tidak punya kesamaan standar sama sekali. Tradisi-tradisi setuju, misalkan, mengenai otoritas hukum logika. ${ }^{33}$ Sekalipun ada persamaan, ini tidak cukup untuk menyelesaikan ketidaksetujuan yang ada. ${ }^{34}$

Hal ini juga tak berarti tradisi-tradisi yang ada imun dari kritikan dan penilaian. ${ }^{35}$ Telaah sejarah menunjukkan satu tradisi bisa ditinggalkan atau dirombak saat dinilai salah. ${ }^{36}$ Kesalahan ini,

... is recognized retrospectively as a past inadequacy when the discrepancy between the beliefs of an earlier stage of an tradi-

\footnotetext{
${ }^{29}$ MacIntyre, Whose, 351; bdk. McGrath, Reality, 66.

${ }^{30}$ MacIntyre, Whose, 350.

${ }^{31}$ Karena itu, diskusi rasional yang berarti hanya dapat terjadi di dalam satu tradisi di mana pihak-pihak yang berdiskusi sama-sama memiliki sejumlah kepercayaan dasar tradisi tersebut. MacIntyre juga menyadari bahwa tidak semua tradisi memiliki suatu rasionalitas yang terstruktur yang karenanya pemikir dalam kerangka Pencerahan menolak mengacuhkan mereka (ibid., 348, 7).

${ }^{32} \mathrm{McGrath}$, Reality, 67.

${ }^{33}$ MacIntyre, Whose, 351.

${ }^{34}$ Ibid.

${ }^{35} \mathrm{McGrath}$, Reality, 67.

${ }^{36}$ Ibid.
}

tion of enquiry are contrasted with the world of things and persons as it has come to be understood at some later stage. ${ }^{37}$

Melihat kedua hal di atas, MacIntyre tidak mau jatuh pada relativisme. ${ }^{38}$ Tradisi yang bersaing sebenarnya dapat dievaluasi. Atas pertanyaan, "Which tradition is to be preferred, and on what grounds?" McGrath merangkum analisis MacIntyre mengenai hal ini dalam dua kriteria. ${ }^{39}$ Pertama, apakah tradisi tersebut memiliki koherensi internal? ${ }^{40}$ Seperti dikatakan sebelumnya, koherensi bukanlah satusatunya kriteria namun syarat apabila suatu rasionalitas hendak menjadi dasar moralitas. Kedua, adakah pertanyaan yang tak terjawab dalam tradisi yang satu dapat dijawab oleh tradisi yang lain? ${ }^{41}$ Dapatkah tradisi yang satu menawarkan penjelasan yang memuaskan bagi tradisi yang lain atas pertanyaan yang selama ini muncul dalam tradisi itu? ${ }^{42}$

Mengelaborasi kriteria kedua MacIntyre, McGrath mengajukan teologi natural Kristen (natural theology) sebagai penjelasan yang punya signifikansi melampaui tradisi Kristen. ${ }^{43}$ Teologi natural Kristen yang dimaksud oleh McGrath bukanlah usaha memberi dukungan atas keberadaan Allah tanpa mengacu pada premis atau presuposisi Kristen. ${ }^{44}$ Bagi McGrath, teologi natural adalah "the enterprise of seeing nature as creation,

\footnotetext{
${ }^{37}$ MacIntyre, Whose, 357.
}

38352-3.

${ }^{39}$ McGrath, Reality, 75 tampaknya merangkum dari MacIntyre, After Virtue (ed., ke-3), xiii.

${ }^{40}$ Ibid.; McGrath, Reality, 75.

${ }^{41}$ Ibid.; MacIntyre, After Virtue xiii.

${ }^{42}$ Ibid.; McGrath, Reality, 75. Tentunya penilaian memuaskan atau tidaknya penjelasan tradisi lain itu tidaklah terlepas dari tradisi yang menilai. Penjelasan yang sama dapat menjadi jawaban yang memuaskan bagi satu tradisi namun tidak memuaskan pada tradisi lainnya.

${ }^{43}$ Ibid. $72-8$.

${ }^{44}$ Definisi natural theology McGrath ini bukan definisi yang sering kali digunakan oleh para apologet seperti William Alston. Definisi para apologet yang tidak dimaksudkannya itu adalah: "the enterprise of providing support for religious beliefs by starting from premises that neither are nor presuppose any religious beliefs" (ibid., 72-3). 
which both presupposes and reinforces fundamental Christian theological affirmations." ${ }^{45}$

Kepercayaan bahwa dunia ini diciptakan oleh Allah adalah dasar, bukan hasil dari teologi natural McGrath. Doktrin penciptaan ini mengasumsikan kebermaknaan dalam ciptaan sehingga membuka ruang untuk satu penjelasan yang koheren dan barangkali menarik bagi tradisi lain. ${ }^{46}$ Upaya Kristen untuk menuangkan pemahamannya mengenai alam dan manusia dari perspektif Kristen inilah yang ia maksud sebagai teologi natural Kristen.

Analisis MacIntyre dan McGrath di atas dapat memberikan pemikir moral Indonesia peta dari situasi diskusi moralitas bangsa. Berbagai standar moralitas dalam tradisi-tradisi di Indonesia pada dasarnya tidak dapat begitu saja diadu atau dilebur di meja debat. Setiap falsafah hidup punya rasionalitasnya sendiri sehingga punya konsep moralitasnya yang perlu dihargai ${ }^{47}$ Daripada memaksakan atau merelakan moralitasnya, tradisi Kristen atau tradisi lain bisa ikut serta di ruang publik untuk memberi pengaruh dan sumbangsih dalam diskusi moralitas bangsa, tanpa perlu melucuti keunikannya. ${ }^{48}$ Keikutsertaan itu bukanlah sebentuk penghakiman bahwa moralitas kepercayaan, atau ideologi lain lebih rendah daripada miliknya. ${ }^{49}$ Partisipasi membangun diskusi moralitas bangsa dimulai dengan menawarkan moralitas Kristen. Langkah penawaran itu pertama-tama adalah

${ }^{45}$ Ibid., 71, 73. Pengaruh dosa tidak ia lupakan: "the human capacity to discern that the patterning of the world is a vestige of its sin, but remains a subtle, if often unacknowledged influence over human reflection."

${ }^{46}$ Ibid., 71, 73, 75.

${ }^{47}$ Perlu ditekankan di sini, tradisi yang berkembang di Indonesia telah lama saling bersentuhan dan saling mewarnai dalam sejarah. Akibatnya, irisan, kemiripan, saling serap, namun juga ketidakcocokan adalah kenyataan yang harus dihadapi. MacIntyre membahas kondisi semacam ini dalam MacIntyre, Whose, 350-1.

${ }^{48}$ McGrath, Reality, 119, lih. Ronald Thiemann, Constructing a Public Theology: The Church in Pluralistic Culture (Louisville: John Knox, 1991).

${ }^{49}$ Tradisi Kristen bisa saja percaya bahwa apa yang diimaninya lebih tepat dan berlaku universal, namun orang Kristen tidak perlu jatuh pada merendahkan tradisi lain. dengan mempraktikkannya, ${ }^{50}$ mempertunjukkan koherensinya, sambil senantiasa membangun dialog yang berisi penawaran konsep Kristen akan realitas yang berkaitan dengan isu-isu moralitas kepada komunitas dari tradisi lain. Harapan di balik tawaran itu adalah diskusi moralitas bangsa diperkaya dan tradisi lain bisa memahami, mengapresiasi, bahkan mengadopsi konsep moralitas Kristen. ${ }^{51}$

McGrath telah memberi contoh tawaran teologi natural yang mungkin bersignifikansi lintas tradisi: perspektif Kristen dalam matematika, pluralitas agama, rasa kagum, dan pencarian akan kebaikan, dll. ${ }^{52}$ Dalam bagian berikut ini, penulis akan mencoba berfokus pada penjelasan tradisi Kristen atas realitas sosial antarmanusia: persahabatan..$^{53}$

\section{Persahabatan Manusia sebagai Perpanjangan Persahabatan dengan Allah}

Berbeda dengan kesimpulan Ander Nygren, persahabatan dengan Allah dan manusia

\footnotetext{
${ }^{50}$ Stanley Hauerwas, Resident Aliens: Life in the Christian Colony (Edisi 25 tahun; Nashville: Abingdon, 2014).

${ }^{51}$ Tugas mempraktikkan dan memastikan koherensi moralitas tradisi Kristen merupakan pekerjaan rumah dari tradisi Kristen dan tidak akan dikejar lebih jauh dalam tulisan ini. Langkah menawarkan moralitas kepada tradisi lainlah yang tampaknya lebih menarik dalam konteks membentuk arah moralitas bangsa dari berbagai tradisi moralitas yang ada di Indonesia.

${ }^{52}$ McGrath, Reality, 78-96.

${ }^{53}$ Penulis memilih persahabatan sebagai konsep yang akan dibahas bukan bermaksud bahwa penjelasan ini pasti menjawab suatu pertanyaan tradisi tertentu. Setiap tradisi pasti memiliki pemikir yang mencoba menjawab setiap pertanyaan muncul dalam tradisinya. Jawaban ini terkadang menjawab, namun terkadang tidak benar-benar pertanyaan dalam tradisi tersebut. Penulis hanya menawarkan suatu realitas yang begitu dekat, namun jarang mendapat perhatian, apalagi penjelasan teologis. Penulis tidak juga menjamin bahwa ini merupakan jawaban terbaik atas suatu permasalahan yang dimiliki oleh tradisi lain. Setiap tradisi memiliki bagian untuk mengulurkan pemahamannya dan mendengar pemahaman tradisi lain. Cocok tidaknya, menjawab tidaknya, memuaskan tidaknya suatu teologi natural suatu tradisi pada akhirnya ada di tangan tradisi-tradisi lain. Harapan yang tersimpan adalah setiap tradisi boleh saling belajar, terpacu, menemukan jawaban bahkan menemukan pertanyaan baru dalam diskusi moralitas antara tradisi. Dalam tulisan ini, pertemanan dan persahabatan akan digunakan secara setara tanpa perbedaan derajat kedekatan di antara kedua istilah.
} 
memiliki tempat yang spesial dalam tradisi Kristen. ${ }^{54}$ Dari Alkitab, Ambrose, Agustinus, Aelred, hingga puncaknya pada pemikiran Aquinas, persahabatan merupakan konsep yang tidak terpisahkan dari konsep kasih (caritas). ${ }^{55}$

Dalam Perjanjian Lama, ada persahabatan yang baik dan yang buruk. ${ }^{56}$ Sahabat yang baik ditunjukkan dalam perbuatan yang baik, teguran yang membangun, dan kesetiaan. Persahabatan yang buruk mengingatkan manusia akan pahitnya pengkhianatan. Persahabatan antara manusia ini tidak dapat dilepaskan

${ }^{54}$ Pengaruh pemikiran Nygren tampaknya membuat persahabatan (philia) tidak terlalu populer di antara orang Kristen. Nygren misalkan membedakan kasih agape yang tidak egois dari Allah dengan kasih eros yang egois dari manusia. Dalam bukunya Agape and Eros, Nygren mengelompokkan philia sebagai bagian dari eros: "egocentric desire is the basis of friendship." Karena pemahaman Nygren, sejak tahun dekade awal abad ke-20, kasih persahabatan dibedakan secara kontras dari kasih Allah dan sedikit banyak termarginalkan sebagai kasih yang egois (Liz Carmichael, Friendship: Interpreting Christian Love [London, New York: T\&T Clark, 2004], 36). Kesimpulan Nygren ini didasarkan pada analisis semantik kata agape dan philia. Sayangnya, analisis Nygren didapati bermasalah oleh James Barr. Dalam "Words for Love in Biblical Greek," Barr menunjukkan bahwa kedua kata tersebut dalam bentuk kata kerjanya memiliki arti yang tumpang tindih. Bahasa Yunani dalam Perjanjian Baru merefleksikan masa di mana kedua kata tersebut merupakan sinonim dengan sedikit atau tanpa perbedaan. Bentuk kata kerja agape memang muncul lebih sering dari bentuk kata kerja philia, namun kedua kata tersebut artinya dekat dan dapat dipakai secara bergantian. Jadi, pembedaan yang berlebihan dari Nygren kurang berdasar. Lebih lanjut lagi, dalam Perjanjian Baru, terutama Injil Yohanes, konsep agape terkait erat dengan persahabatan (James Barr, "Words for Love in Biblical Greek" dalam The Glory of Christ in the New Testament: Essays in Honour of George Caird [ed., L. D. Hurst dan N. T. Wright; Oxford: Clarendon, 1987], 3-18 sebagaimana dalam Carmichael, Friendship, 37-39). Melihat, hal ini pembedaan yang dilakukan C.S. Lewis terhadap empat penggunaan kasih dalam Alkitab juga tidak terlalu menolong (bdk. C.S. Lewis, Four Loves [cet. ulang 1960; London: Collins, 1983]).

${ }^{55}$ Tahun 1929, misalnya, Student Christian Movement di Liverpool mengangkat persahabatan antara bangsa, antara manusia, dan terutama antara manusia dengan Allah menjadi misi utama Allah. Lih. survei sejarah konsep persahabatan yang sangat baik dalam Carmichael, Friendship, 7-195, 154 ; bdk. Victor Austin, Christian Ethics: A Guide for the Perplexed (New York: Bloomsbury, 2012), 120-7.

\footnotetext{
${ }^{56}$ Ibid., 117.
}

dengan relasi manusia dengan Allahnya. ${ }^{57}$ Mazmur 15:3, misalnya, menjelaskan orang yang boleh berdiam di kediaman Allah adalah yang tidak berbuat jahat pada temannya. ${ }^{58}$

Selain itu, relasi Allah dengan manusia juga dinyatakan dalam bentuk persahabatan, terutama dalam kisah Abraham dan Musa (Kel. 33:11; 2Taw. 20:7; Yes.41:8). ${ }^{59}$ Antara Allah dan sahabat-Nya ada percakapan muka dengan muka yang menggambarkan keintiman dan persekutuan yang timbal balik. ${ }^{60}$

Di Perjanjian Baru, Yesus mentransformasi persahabatan, baik persahabatan antara Allah dengan manusia ataupun persahabatan antarmanusia. ${ }^{61}$ Dalam Injil Matius, misalnya, pembaca diperhadapkan pada Yesus yang menjadi teman bagi semua orang, bahkan mereka yang berdosa. Tidak heran epitet "sahabat pemungut cukai dan orang berdosa" menjadi label yang dikenakan pada Sang Anak Manusia (11:19). Meskipun begitu, sahabat juga bisa menjadi kata yang menekankan ironi kekecewaan Yesus akan manusia yang tidak berlaku sebagai teman yang baik. ${ }^{62}$ Dalam Injil Lukas, pengadilan Yesus menyebabkan persahabatan yang ironis di antara mereka yang mengadiliNya. ${ }^{63}$ Selain itu, Yesus dalam perumpamaanNya menjadi sosok yang memanggil, mengundang, dan membawa murid-Nya lebih dekat pada-Nya dengan sebutan sahabat. ${ }^{64}$

${ }^{57}$ Ibid.

${ }^{58}$ Ibid.

${ }^{59}$ Christopher Heuertz dan Christine Pohl, Friendship at the Margin (Resources for Reconciliation; Downers Grove: Inter-Varsity, 2010), 29.

${ }^{60}$ Austin, Christian Ethics, 117-8.

${ }^{61}$ Carmichael, Friendship, 35.

${ }^{62}$ Klimaksnya tentu ada di dalam kalimat terakhir Yesus kepada Yudas: "Hai teman, untuk itukah engkau datang?" (Mat. 26:50). Lih. Austin, Christian Ethics, 119.

${ }^{63}$ Setelah Herodes dan Pilatus bolak-balik mengadili Yesus, Lukas memotong narasinya dengan "dan pada hari itu juga bersahabatlah Herodes dan Pilatus; sebelum itu mereka bermusuhan" (Luk. 23:12).

64"Sahabat, silakan duduk di depan. Dan dengan demikian engkau akan menerima hormat di depan mata semua tamu yang lain" (Luk. 14:10). 
Jika kedua Injil ini menekankan Yesus datang untuk menjadi sahabat bagi manusia, Injil Yohanes menjadikan persahabatan sebagai sesuatu yang krusial dalam karya kasih Kristus. Dalam Yohanes 15:13-15, Yohanes menarasikan satu bagian yang menjadi fokus pengertian Kristen akan persahabatan. ${ }^{65}$ Yesus memanggil murid-Nya bukan lagi sebagai hamba tetapi sebagai sahabat. Ia sendiri yang memulai persahabatan itu dengan mereka ketika Ia menyerahkan nyawa-Nya untuk mereka. Mengaitkan kasih pengorbanan-Nya dengan persahabatan-Nya, Yesus menunjukkan kasih sempurna yang Ia harapkan para murid hidupi juga. ${ }^{66}$

Meramu pengertian persahabatan dalam Alkitab dan literatur Yunani klasik, Thomas Aquinas, the greatest theologian of friendship, ${ }^{67}$ mengamati bahwa caritas dan persahabatan sama-sama menunjukkan kasih dalam bentuknya yang paling sempurna.$^{68}$ Karena itu, Aquinas menyimpulkan persahabatan (amicitas) ${ }^{69}$ adalah kasih ilahi (caritas).$^{70}$ Melalui perumusan seperti ini, Aquinas berhasil memberi ruang yang sentral bagi kasih-persahabatan antara manusia dengan Allah dan kasih-persahabatan antarmanusia sebagaimana yang dinyatakan dalam Yohanes 15.

Seperti Aristoteles, Aquinas menjelaskan bahwa persahabatan pada dasarnya adalah

65“Tidak ada kasih yang lebih besar dari pada kasih seorang yang memberikan nyawanya untuk sahabat-sahabatnya. Kamu adalah sahabat-Ku, jikalau kamu berbuat apa yang Kuperintahkan kepadamu. Aku tidak menyebut kamu lagi hamba, sebab hamba tidak tahu, apa yang diperbuat oleh tuannya, tetapi Aku menyebut kamu sahabat, karena Aku telah memberitahukan kepada kamu segala sesuatu yang telah Kudengar dari Bapa-Ku.”

${ }^{66}$ Heuertz, Friendship, 29.

${ }^{67}$ Carmichael, Friendship, 101.

${ }^{68}$ Ibid., 106.

${ }^{69}$ Persahabatan adalah amicitas dalam bahasa Latin.

70 ". . Christian love, caritas, fully and in every respect as friendship, amicitia" (ibid., 101, 105-6). Caritas dalam bahasa Latin berarti charity sekaligus love dalam bahasa Inggris. Dalam pengertian aslinya, caritas merujuk pada kasih kristiani yang ideal sebagaimana ditunjukkan di dalam diri Yesus. Karena tidak adanya padanan yang sempurna dalam bahasa Indonesia, penulis menerjemahkan caritas sebagai kasih sempurna. berbagi hidup. ${ }^{71}$ Karena Yesus telah menyerahkan nyawa-Nya untuk orang percaya, Allah telah membagikan hidup-Nya kepada kita sebagai bentuk caritas yang adalah amicitas-Nya dengan orang yang percaya. ${ }^{72}$ Caritas yang dituangkan Roh Kudus dalam hidup orang Kristen adalah amicitas itu sendiri. Alhasil, orang percaya menjadi sahabat (amicus) Allah. Dengan kata lain, caritas mentransformasi pribadi-pribadi yang terlibat menjadi amicus. Persahabatan ini tidak diinisiasi oleh manusia, melainkan oleh Allah yang menunjukkan caritas- $N$ ya dengan membagikan hidup-Nya bagi kita sekalipun kita masih berdosa. ${ }^{73}$

Melalui kontempelasi di dalam Roh Kudus, orang percaya berelasi timbal balik dengan Allah. ${ }^{74}$ Tidak hanya itu, Allah juga hadir dalam dan kepada sesuatu sehingga relasi manusia dengan Allah timbal balik sebagaimana relasi persahabatan antara manusia. ${ }^{75}$

Dalam mengasihi seorang sahabat, Aquinas mengamati, manusia akan mengasihi juga orang yang dikasihi oleh sahabatnya itu. ${ }^{76}$ Lantaran itu, jika orang Kristen mengasihi Allah yang telah mengasihi dan telah menjadi sahabatnya, ia mengasihi juga segala sesuatu yang dikasihi Allah. ${ }^{77}$ Karena Allah telah mengasihi segala yang ada dengan menciptakan segala yang ada, orang Kristen pun mengasihi dan menjadi sahabat bagi segala sesuatu yang ada karena Allah. ${ }^{78}$ Mengenai hal ini, Aquinas berbeda pendapat dengan Aristoteles yang membatasi persahabatan hanya pada segelintir orang. ${ }^{79}$ Bagi Aquinas, persahabatan dengan Allah membuat kita pada dasarnya mengasihi segala milik Allah

\footnotetext{
${ }^{71}$ Ibid., 105-6.

${ }^{72}$ Ibid., 107-8, 105.

${ }^{73}$ Ibid., 110, 109.

${ }^{74}$ Ibid., 108.

${ }^{75}$ Ibid.

${ }^{76}$ Ibid., 106.

${ }^{77}$ Ibid., 121

${ }^{78}$ Ibid.

${ }^{79}$ Ibid., 106.
} 
dan pada gilirannya menjadikan diri kita sahabat dari segalanya. ${ }^{80}$

Kepada semua manusialah amicitas Allah bisa menjadi nyata sepenuhnya. Baik mereka yang mengenal Allah atau yang berdosa sama-sama bisa menjadi amicus Allah dalam arti sepenuhnya. ${ }^{81}$ Walaupun begitu, Aquinas tidak menjadikan persahabatan begitu universal hingga tak bermakna lagi. Aquinas percaya bahwa hanya mereka yang telah menerima curahan caritas Allah Bapa di dalam Kristus melalui Roh Kudus yang telah betul-betul menjadi amicus Allah. Mereka inilah sahabat Allah yang berbagian dalam persekutuan (koinonial societas) dengan Allah dan sesama sahabat Allah. ${ }^{82}$ Karena kasihnya pada Allah, Sahabat yang terutama, satu sahabat dengan aktif belajar menyerahkan nyawanya untuk sahabatnya lain. ${ }^{83}$ Ini adalah tanda bahwa mereka adalah sahabat Allah (Yoh. 15:12, 14). ${ }^{84}$ Ini juga menurut kategori Aquinas merupakan kebajikan (virtue). ${ }^{85}$

Bagaimana dengan mereka yang berdosa dan masih terpisah dari Allah? Aquinas menjawab:

\footnotetext{
${ }^{80}$ Aquinas berkata Allah, "extends friendship in its fullest sense to rational creatures alone, to all 'antecedently'...." (ibid., 107) Alam adalah ciptaan dan milik Allah dan menerima sebentuk caritas, namun alam bukanlah amicus Allah. Alam bukanlah ciptaan rasional yang bisa benar-benar memiliki persahabatan dengan Allah dan manusia. Sampai di sini, relevansi ekologis dari etika yang lahir dari penjelasan tradisi Kristen tentang realitas persahabatan sudah dapat diendus. Alam bukan amicus Allah dalam pengertian penuh, melainkan "as when we love a human friend we love all who belong or pertain to them, even those among them who do not return love to us (ibid., 106, bdk. 116)," maka sahabat Allah mau tidak mau akan merentangkan juga caritas kepada ciptaan-Nya yang lain. Tentu derajat prioritas caritas yang sahabat Allah ulurkan bagi manusia dengan alam berbeda. Meski demikian, apabila orang Kristen sepenuhnya melalaikan tanggung jawabnya mengalirkan caritas Allah pada alam milik Allah ini, maka agak sulit mengatakan bahwa kasih Allah benar-benar ada dalam dirnya. Ini barangkali salah satu gambaran implikasi moral dari konsep persahabatan Aquinas.
}

\footnotetext{
${ }^{81}$ Ibid., 121.

${ }^{82}$ Ibid., 107.

${ }^{83}$ Ibid., 109.

${ }^{84}$ Ibid.

${ }^{85}$ Ibid., 113-7.
}

... we extend friendship to someone either on their own account, or on account of someone else. We can, he persuades us, so greatly love a friend that we also love their entire household and all their connections, whether the latter are friendly to us or not. Therefore to the extent that we love God, we shall also show love to our neighbour, just as we love a friend's children however unfriendly they may seem to us (II-II 25.8). Thus 'the friendship of charity extends even to our enemies, whom we love out of charity in relation to God, to Whom the friendship of charity is chiefly (principaliter) directed' (II-II 23.1 ad $2)^{86}$

Baik orang kudus maupun orang bejat adalah milik Allah dan berpotensi menjadi sahabat Allah. Karena itu, friendship with God introduces us into God's universal friendship, in which we are commanded to love every person as our neighbour. ${ }^{87}$ Semakin dalam kasih seorang sahabat Allah, semakin dalam ia mengasihi, baik yang dekat maupun yang asing dan bermusuhan dengannya. ${ }^{88}$ Sahabat Allah mengasihi mereka yang berdosa bukan atas dasar keberdosaan mereka, namun karena mereka adalah sesama gambar dan rupa Allah yang memiliki potensi menerima anugerah Allah. Sahabat Allah mengasihi dengan caritas mereka yang belum menerima sepenuhnya caritas Allah dengan harapan mereka menerima caritas Allah sehingga menjadi amicus Allah sepenuhnya. ${ }^{89}$ Dalam berbagi caritas pada mereka yang berdosa, sahabat Allah menengok pada Yesus yang adalah sahabat orang berdosa. Yang hari ini pendosa,

\footnotetext{
${ }^{86}$ Ibid., 121.

${ }^{87}$ Ibid., 121.

${ }^{88}$ Ibid., 123.

${ }^{89}$ Ibid., 121-3.
} 
di masa depan barangkali akan bersukacita akan Allah dengan kita. ${ }^{90}$

Although sinners do not return our love now, it remains true that they are born to do so, especially in the life to come. That shared life already exists in potential in the present, uniting those who are still strangers on earth. 'Caritas never ends towards anyone in this life, however bad they may be, because in this life, within the economy of divine mercy, the possibility of the life of glory remains. ${ }^{91}$

Antara Allah, sahabat Allah yang lain, dan orang berdosa, para sahabat Allah nyatanya tidak mampu mengasihi mereka secara seimbang. ${ }^{92}$ Kepada semuanya caritas harus ditujukan, namun prioritas merupakan sesuatu yang tak terelakkan. Allah niscaya mendapat prioritas kasih. Sahabat Allah mengasihi segala sesuatu karena dan di dalam Dia.

Bagi Aquinas antara sesama sahabat dan orang berdosa, kasih yang lebih kuat seharusnya diberikan pada yang paling dekat kepada Allah. ${ }^{93}$ Sekalipun demikian, dalam kondisi tertentu, mengasihi orang berdosa tampak lebih baik dan mulia daripada mengasihi seorang teman. Matius, misalnya, mengatakan kasih kepada teman tidak spesial namun kasih atas musuh yang melanggar kita layak mendapat imbalan. ${ }^{94}$ Menimbang kedua hal ini, pada akhirnya, bagi Aquinas:

"Love for God is proved stronger and furnace-like if its heat reaches across distance to an enemy, but on the other hand, just as

${ }^{90}$ Sampai di sini, implikasi konsep persahabatan Aquinas bagi misi perlu diangkat. Apabila caritas Allah itu adalah persahabatan, misi yang berusaha membawa caritas itu harus membawa orang dari kepercayaan lain bukan hanya percaya karena percakapan dengan orang asing yang bermodalkan traktat, namun hadir sebagai sahabat dan mengundang orang itu ke dalam persahabatan dengan Allah dan sesama sahabat Allah. Pohl mengutip Jack Pullinger berkata, "Don't tell someone about Christ unless you're willing to give them your bed" (Heuertz, Friendship, 42). Di sini, persahabatan, misi, dan hospitalitas bertemu untuk menghadirkan Injil yang sepenuhnya.

${ }^{91}$ Ibid., 122-3.

${ }^{92}$ Ibid., 124.

${ }^{93}$ Ibid.

${ }^{94}$ Ibid. a fire best warms those closest to it 'charity loves with greater fervor those who are united to us than those who are far removed; and in this respect the love of friends, considered in itself, is more ardent and better than the love of one's enemy. ${ }^{95}$

Jadi, tradisi Kristen, sebagaimana tergambar dalam pembacaan Aquinas, mengerti persahabatan sebagai kasih yang tertinggi. Kasih yang sempurna ini pertama-tama diulurkan Allah bagi orang berdosa yang dijadikan-Nya sebagai sahabat. Kasih itu kemudian meluap melalui kasih sahabat-sahabat-Nya kepada segala sesuatu yang adalah milik Allah, seberapa jauh, asing, berdosa, bahkan terpinggirkannya mereka. ${ }^{96}$ Di dalam persahabatan inilah manusia saling memberikan nyawanya bagi Allah dan sesamanya sambil menanti konsumasi eskatologis. ${ }^{97}$ Surgalah pertemuan muka dengan muka antara para sahabat dengan "Friend of friends" untuk selamanya tinggal bersama dalam sukacita. ${ }^{98}$

\section{Kesimpulan}

Lewat sekelumit pembahasan di atas, penulis telah memaparkan penjelasan dari perspektif Kristen mengenai pertemanan sebagai realitas sosial antara manusia. Kasih persahabatan dalam perspektif Kristen bukan hanya berkaitan dengan manusia, namun dengan Allah. Antara sesama sahabat Allah, ada kasih dan persekutuan yang kuat. Karena didasarkan

${ }^{95}$ Ibid., 125.

${ }^{96}$ Menariknya, persahabatan mempunyai implikasi penting bagi pribadi-pribadi dengan kebutuhan khusus (disability), lih. Hans Reinders, Receiving the Gift of Friendship: Profound Disability, Theological Anthropology, and Ethics (Grand Rapids: Eerdmans, 2008) 279-374.

${ }^{97}$ Austin, Christian Ethics, 126-7.

${ }^{98}$ Charlie Andrews, What I owe to Christ (London: Hodder, 1932), 19. Andrews adalah seorang misionaris di India yang adalah sahabat dari Mahatma Gandhi dan pejuang kemerdekaan India. Di sana, ia dikenal sebagai Deenabandhu atau "teman dari mereka yang menderita." Sering berbicara mengenai Yesus sebagai sahabat, ia berkata: "He, the Friend of the friendless, will not allow us to neglect them [the poor] or to send them empty away" (idem, Christ and Human Need (London, 1937), 12 sebagaimana dalam Carmichael, Friendship, 203). Andrews barangkali adalah contoh nyata perwujudan misi persahabatan Allah bagi dunia. 
pada Allah, persahabatan bisa diulurkan juga bahkan kepada orang yang berdosa, bahkan yang berbuat kekejian pada orang Kristen.

Penjelasan seperti ini sifatnya tawaran. Tidak ada jaminan bahwa penjelasan dari tradisi Kristen ini akan memuaskan tradisi yang lain. Setiap tradisi memiliki pergumulan, rasionalitas, dan standar kepuasan tersendiri. Walaupun demikian, dialog yang dipenuhi saling tukar penawaran konsep seperti ini menolong setiap tradisi dalam diskusi. Bertemu dengan pemahaman tradisi lain, setiap tradisi diajak memikirkan kembali pemahaman tradisinya mengenai moralitas, bertanya pertanyaan lama, bahkan bertanya pertanyaan baru. Barangkali kemudian ada perubahan yang perlu terjadi dalam satu tradisi karena tawaran tradisi lain yang didapati menarik dan relevan untuk diadopsi.

Melalui proses panjang ini, setiap tradisi, termasuk Kristen punya sumbangsih dalam diskusi moralitas bangsa. Tradisi Kristen mendapat kesempatan menggarami tradisi lain dan mewarnai diskusi yang terjadi seputar pengambilan keputusan publik. Tidak tertutup juga kemungkinan tradisi Kristen belajar sesuatu dari tradisi lain yang memperkaya dan menerangi titik-titik buta yang belum digali selama ini. 


\section{Daftar Kepustakaan}

Austin, Victor. Christian Ethics: A Guide for the Perplexed. New York: Bloomsbury, 2012.

Bertens, K. Etika. Cetakan ke-2. Jakarta: Gramedia, 1994.

Birch, Bruce, dan Larry Rasmussen. Bible and Ethics in Christian Life. Minneapolis: Augsburg, 1989.

Boulton, Wayne, Thomas Kennedy, dan Allen Verhey, "An Introduction to Christian Ethics" dalam From Christ to the World. Grand Rapids: Eerdmans, 1994.

Braaten, Carl, dan Christopher Seitz, ed. I Am the Lord Your God: Christian Reflection on Ten Commandments. Grand Rapids, 2005.

Cahill, Lisa, dan James Childress, ed. Christian Ethics: Problem and Prospect. Cleveland: Pilgrim, 1996.

Carmichael, Liz. Friendship: Interpreting Christian Love. London, New York: T\&T Clark, 2004.

Childs, Brevard. Biblical Theology in Crisis. Philadelphia: Westminster, 1970.

Cosgrove, Charles. Appealing to Scripture in Moral Debate: Five Hermeneutical Rules. Grand Rapids: Eerdmans, 2002.

Darmaputera, Eka. Sepuluh Perintah Allah: Museumkan Saja? Yogyakarta: Gloria Graffa, 2005.

Feinberg, John, dan Paul Feinberg. Ethics for a Brave New World. Ed. ke-2. Wheaton: Crossway, 2010.

Gill, David. Doing Right: Practicing Ethical Principle. Downers Grove: Inter-Varsity, 2004.

Gustafson, James. "The Place of Scripture in Christian Ethics: A Methodological Study," Interpretation 24 (1970) 430-455.

Hanson, Paul. Political Engagement as Biblical Mandate. Eugene: Cascade, 2010.

Hauerwas, Stanley. A Community of Character. Notre Dame: University of Notre Dame Press, 1981.

Heuertz, Christopher, dan Christine Pohl, Friendship at the Margin. Resources for Reconciliation. Downers Grove: Inter-Varsity, 2010.

Hiebert, Paul. Cultural Anthropology. Edisi. ke-2. Grand Rapids: Baker, 1983.

James Barr, "Words for Love in Biblical Greek" dalam The Glory of Christ in the New Testament: Essays in Honour of George Caird. Diedit oleh L.D. Hurst dan N.T. Wright. Oxford: Clarendon, 1987.

Kaiser, Walter. Toward Old Testament Ethics. Grand Rapids: Academie, 1983.

Kallenberg, Brad. "Positioning MacIntyre within Christian Ethics" dalam Virtues and Practices in the Christian Tradition: Christian Ethics after MacIntyre. Cetakan. ke-2. Diedit oleh Nancey Murphy, Brad Kallenberg, dan Mark Nation. Notre Dame: University of Notre Dame Press, 2003.

. "The Master Argument of MacIntyre's After Virtue" dalam Virtues and Practices in the Christian Tradition: Christian Ethics after MacIntyre. Cetakan. ke-2. Diedit oleh Nancey Murphy, Brad Kallenberg, dan Mark Nation. Notre Dame: University of Notre Dame Press, 2003. 
Kuhn, Thomas. The Structure of Scientific Revolutions. Chicago: University of Chicago Press, 1970.

Lewis, C.S. Four Loves. Cetakan ulang dari 1960. London: Collins, 1983.

MacIntyre, Alasdair. Whose Justice? Which Rationality? Notre Dame: University of Notre Dame Press, 1988.

. "Rival Justice, Competing Rationalities," This World: A Journal of Religion and Public Life 21 (1988) 78-94.

. After Virtue: A Study in Moral Theory. Edisi. ke-3. Notre Dame: University of Notre Dame Press, 2007.

Mahaney, C.J., ed. Worldliness. Wheaton: Crossway, 2013.

McGrath, Alister. Reality. A Scientific Theology. Grand Rapids: Eerdmans, 2002.

Reinders, Hans. Receiving the Gift of Friendship: Profound Disability, Theological Anthropology, and Ethics. Grand Rapids: Eerdmans, 2008.

Thompson, James. Moral Formation according to Paul: The Context and Coherence of Pauline Ethics. Grand Rapids: Baker, 2011.

Verhey, Allen. Reading Bible in the Strange World of Medicine. Grand Rapids: Eerdmans, 2003. 
